\title{
Best Irrigation Practices Designed for Pesticides Use to Reduce Environmental Impact on Groundwater Resource in the Tunisian Context
}

\author{
Béchir Ben Nouna ${ }^{1}$, Mourad Rezig ${ }^{1} \&$ Hassouna Bahrouni ${ }^{1}$ \\ ${ }^{1}$ Institut National de Recherches en Génie Rural Eaux et Forêts, Rue Hédi Elkarray, Ariana, Tunisie \\ Correspondence: Béchir Ben Nouna, Institut National de Recherches en Génie Rural Eaux et Forêts, Rue Hédi \\ Elkarray, Ariana, Tunisie. Tel: 216-98-560-800. E-mail: bennouna.bechir@iresa.agrinet.tn \\ Mourad Rezig, Institut National de Recherches en Génie Rural Eaux et Forêts, Rue Hédi Elkarray, Ariana, \\ Tunisie. Tel: 216-98-576-500. E-mail: rezigue_mourad@yahoo.fr
}

\author{
Received: December 29, 2015 Accepted: April 14, 2016 Online Published: June 15, 2016 \\ doi: $10.5539 /$ jas.v8n7p142 \\ URL: http://dx.doi.org/10.5539/jas.v8n7p142
}

\begin{abstract}
The irrigated areas in Tunisia were esteemed in 2010 to over 420 thousand hectares and represents $8 \%$ of farmland, this little area providing $35 \%$ of the total crop production. This situation makes it exert enormous pressure on the irrigated sector that his intensification is very associated to increased inputs including especially pesticides. However, the irrational use and abuse of pesticides associated with an inadequate irrigation system management are a great threat of contamination to groundwater resources and constitute one of the greatest challenges facing Tunisian government today. According to FAO, 2013, the adoption of the concept of best practices can meet this challenge. These best practices are not only a practice that are best, but a practices that have been proven to work well and produce good results, and are therefore recommended as a model. This paper aims to analyze in a framework of global environmental approach, the role of the best irrigation practices (BIPs) to reduce environmental impact on groundwater resource. Finally, it was proposed a set of best irrigation practices completed by the technical recommendations for limiting the environmental impact of pesticide in groundwater resource.
\end{abstract}

Keywords: Best Irrigation Practices (BIPs), groundwater resource, pesticide, environmental tradeoff

\section{Introduction}

Land and water resources and the way they are used are central to the challenge of improving food security across the world. The irrigation sector claims about $70 \%$ of the freshwater withdrawals worldwide. In summary, irrigation is widely thought to provide $40 \%$ of the world's food from around 17 percent of the cultivated area (FAO, 2011). It has been estimated about $\$ 2$ billion are spent on irrigation investment each year (Faurés et al., 2007). The agriculture sector and especially the irrigation sector are most depending to pesticides for production of the high-quality crops. In fact, pesticides have now become an integral part to protect agricultural land. It has been estimated about $\$ 38$ billion are spent on pesticides each year (Pan-Germany, 2012).

In Tunisia, the water consumption of irrigated land makes $80 \%$ of the volumes distributed to all economic sectors of the country. Half of this volume is assured by the groundwater resource (ITES, 2014). However, the quality of groundwater resource is very threatened by the contamination concerning excessive use of fertilizers and especially pesticides from cropland (ITES, 2014). In fact, Tunisia imports every year about 4000 tons of pesticide, (mainly used for weed crop) and the average amount of active substance per application and per hectare is high (about $4 \mathrm{~kg}$ ), also the used volume remains exaggerated (300 liter/ha) (Bahrouni et al., 2015). This reflects the absence of a global vision which shows no link between irrigation system management and the hug quantity of pesticides used. This situation, should lead necessarily to urgent need for a national action to consider the environmental aspect. On the other hand, the movement of pesticides in the environment depends upon a multitude of factors including soil characteristics, site features, pesticide properties and pesticide use practice. Lal (2008) has proved that the of-farm movements of soil and associated compounds from cropland are due to irrigation or rainfall-induced surface runoff. In the same context, Stephen (2004), has showed that the irrigation traditional methods are characterized by low water application efficiency and a high amount of 
irrigation application; which causing a high leaching. In fact, the mastery of the irrigation system management offers tremendous scope to control runoff, and to minimize the contamination of groundwater resource (Jensen et al., 1990). In this sense, Mchugh et al. (2008) have demonstrated that subsurface drip irrigation under deficit irrigation has the potential to store in-crop rainfall more than subsurface drip under full and furrow irrigation in terms of runoff reduction carrying pesticides under rainstorm conditions.

In this context, the groundwater resource protection is a compromise factor for a sustainable use of pesticides and will constitute one of the greatest challenges facing Tunisian government today. Two main strategies could be considered (i) optimize the use of pesticides through Integrated Pest Management (IPM) approach, and (ii) reduce the environmental impact by using the best irrigation practices (BIPs). However, in the last approach, the reduction of the pesticide leaching to groundwater can reach $50 \%$ when the best irrigation practices are considered (Spurlok, 2000).

The objective of this study was to investigate the effect of the main factors influencing the Groundwater contamination potential by pesticides and suggests a best irrigation practices (BIPs) for reducing pesticides loss from cropland. Finally, this work was completed by the technical recommendations for limiting the environmental impact of pesticide in groundwater resource.

\section{Tunisian Context and Environmental Tradeoff Concept}

Many studies in Tunisian aquifer are demonstrated that the phreatic part of groundwater resources is environmentally vulnerable (Raad, 2005; Saidi, 2006; Saidi et al., 2010; Carrubba, 2014). The latter is known by two types. The horizontal vulnerability is due to seawater intrusion caused by overexploitation of groundwater resources whereas a vertical is generated due to drainage of fertilizers and pesticides. The coastal aquifers are subjected to horizontal and vertical vulnerability, while aquifers within the country are subjected only to vertical vulnerability. Regarding the vertical vulnerability study we mention the aquifer case of Hajeb Jelma located in central Tunisia. The evaluation of the potential contamination of this aquifer by the DRASTIC model that is consistent with a national basis allowed to draw its vulnerability map (Saidi et al., 2010). This vulnerability map established to Hajeb-Jelma aquifer shows three classes of contamination: moderate, high and very high. Moreover, the other evaluation result concerns the coastal aquifer in the Ghar El Melh area that is obtained through applying the A.C.V.M methodology (Aquifer Comprehensive Vulnerability Mapping) of the cartography of the horizontal and vertical vulnerability (Carrubba, 2014). This methodology was used to map the aquifer's comprehensive vulnerability the combination of vertical and horizontal vulnerability.

Globally, the contamination of the most Tunisian aquifers which were both already mentioned (Hajeb Jelma, and Ghar El Melh) is mainly due to an increase in the use of agricultural inputs such as chemical fertilizers and pesticides during the last decades. In this context, we noted the absence of a global vision which shows no link between irrigation management and the contamination level by pesticides of soil and groundwater resources.

This reflects an urgent need for a national action to consider the environmental aspect. Indeed, we ask this critical question, how to reduce the environmental impact from pesticides upon groundwater resources? Especially, in the case of agricultural production systems, which are intensified by the enormous amounts of pesticides, and irrigation water volumes, are not well controlled. In Tunisia, we noted, about 4000 tons of pesticide are imported every year, mainly used for weed crop spraying on cereals. Also the sprayed amounts per application and per hectare are high (about $4 \mathrm{~kg} / \mathrm{ha}$ at a rate of 300 liter/ha) (Bharouni et al., 2015), and the average demand of irrigation water per hectare is estimated by $5500 \mathrm{~m}^{3}$ (ITES, 2014).

In fact, the remainder accumulates in soils, where it may filter especially into groundwater or surface water and prove toxic to micro-organisms, aquatic animals, and humans.

Further to these circumstances, we are witnessing the emergence of great challenge of the environmental tradeoff between two main pillars which are the irrigation demand and pesticides use. Indeed, this represents the only loophole alternative to boost agricultural production system, in order to meet the galloping food demand of the population. Thus, it constitutes an environmental tradeoff concept, which can be motivated in part by the political demands for sustainable agricultural production technologies. The structure of this concept can be formed by several components (Figure 1). 


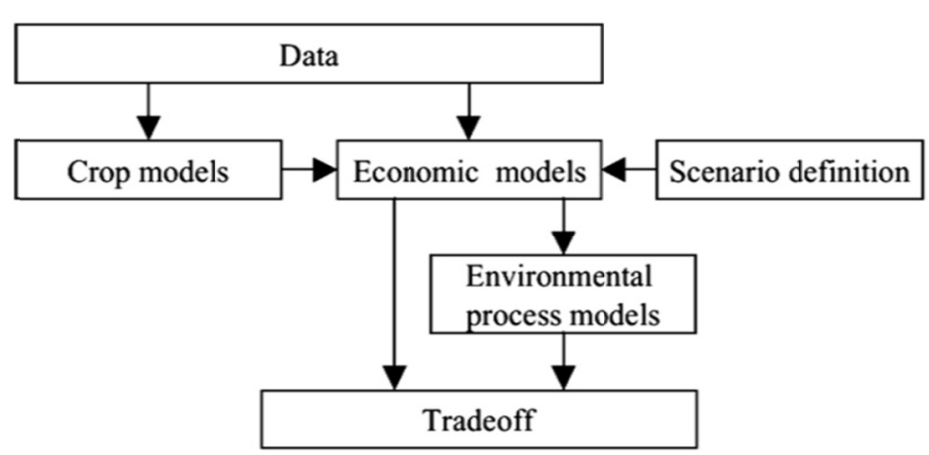

Figure 1. General setup, of the environmental tradeoff concept

However, the tradeoff concept mainly functions as an integrator of different tools and models. For example, crop growth simulation is carried out by models from the DSSAT suite of models (Jones et al., 1998), economic simulation models, and fate simulation of pesticide by environmental process model (LEACHP model, Wagenet \& Hutson, 1989). The Tradeoff approach moves the necessary input and output among the different models and provides a format for the coordination of different scenario runs. This integrated approach will allow us to propose a compromise solution according to the adopted scenario between the efficient use of water resources and pesticides.

\section{How to Reduce the Environmental Impact from Pesticides upon Groundwater Resources?}

To answer to this question is not easily affordable. In fact, the environmental problem can not only be approached from a planning and strategic viewpoint (modeling tools with a data set) but schould be integrate a technical and tactic approach (IPM concept) and innovative concept (BIPs). Indeed, Environmental Global approach in this work is to consider the planning strategic concept (environmental tradeoff) consolidated by the technical tactic concept (IPM) and the innovative concept (BIPs). This work will be focused on the role of these best practices that will feed their towers and consolidate the concept of environmental tradeoff that takes into account to the aspect of sustainability of agricultural production system. Before presenting the Environmental Global approach that we have adopted in this work, we recall the main factors that influence the potential contamination of groundwater.

\subsection{Main Factors Influencing the Groundwater Contamination Potential}

The groundwater contamination is the source of several processes causing the movement of pesticides in water through the soil. The main factors influencing whether pesticides will be leached into groundwater include characteristics of the soil and pesticide, and their interaction with water from a rain-event such as irrigation or rainfall. Table1 summarizes the factors influencing the groundwater contamination potential by pesticides.

Table 1. Factors influencing the Groundwater contamination potential (McBride, 1989)

\begin{tabular}{lll}
\hline \multicolumn{1}{c}{ Summary of Groundwater Contamination Potential as Influenced by Water, Pesticide and Soil Characteristics } \\
\cline { 2 - 3 } & \multicolumn{2}{c}{ Risk of Groundwater Contamination } \\
\cline { 2 - 3 } $\begin{array}{l}\text { Pesticide Characteristics } \\
\text { Water Solubility }\end{array}$ & Low & High risk \\
Soil Adsorption & High & High \\
Persistence & Low & Low \\
\hline Soil Characteristics & Fine Clay & High \\
Texture & High & Coarse Sand \\
Organic matter & Few, Small & Low \\
Macropores & Deep (30 m or more) & Many, Large \\
Depth to groundwater & Shallow (7 m or less) \\
\hline Water Volume & Small Volumes at Infrequent & Large Volumes at Frequent Intervals \\
Rain/Irrigation & &
\end{tabular}


The major part of Tunisian phreatic groundwater is characterized by a vertical vulnerability to chemicals contamination, especially from pesticides that constitute a basic product for agricultural intensification. To prevent or reduce this environmental impact from pesticides to groundwater, users must consider many different site-specific best management practices, including the following: integration of crop and Integrated pest management (IPM), product selection, application rates, timing, placement in relation to the root system, weed cover, soil properties, best soil management practices (BMPs), and best irrigation management practices (BIPs). However, in the last approach, the reduction of the pesticide leaching to the groundwater can reach $50 \%$ when adequate best irrigation practices (BIPs) is considered (Spurlok, 2000).

\subsection{Environmental Global Approach}

The Integrated Pest Management approach (IPM), requires consideration of pesticide selection, when the choice exists, prior to application. Pesticide selection should not be based only on cost effectiveness, but also on toxicity to non-target species, product solubility, persistence, leaching potential, irrigation schedule, soil type, and other site characteristics.

In fact, the new evidence concerning the groundwater environmental protection in this work is to consider simultaneously the irrigation management by the BIPs concept as an essential component to strengthen the pesticides management by the IPM concept. These concepts constitute a great consolidation for the environmental Tradeoff concept and so for the decision-making (Figure 2).

Figure 2 summarizes the environmental global approach to be considered to limit the contamination of the groundwater. In the technical tactic part of our approach, two concepts have been identified, where the intensification of agriculture must the take into account. These tow concepts are: IPM concept related to pesticides management, and BIPs concept related to the mastery of pesticide leaching by irrigation management. In the planning strategic part of approach, the environmental tradeoff concept integrating the planning tools for future scenarios in order to achieve the robust decision-making for a sustainable development of the agricultural production system. In this article, we focus in the technical tactic approach which is based on the innovative concept (BIPs) and IPM concept.

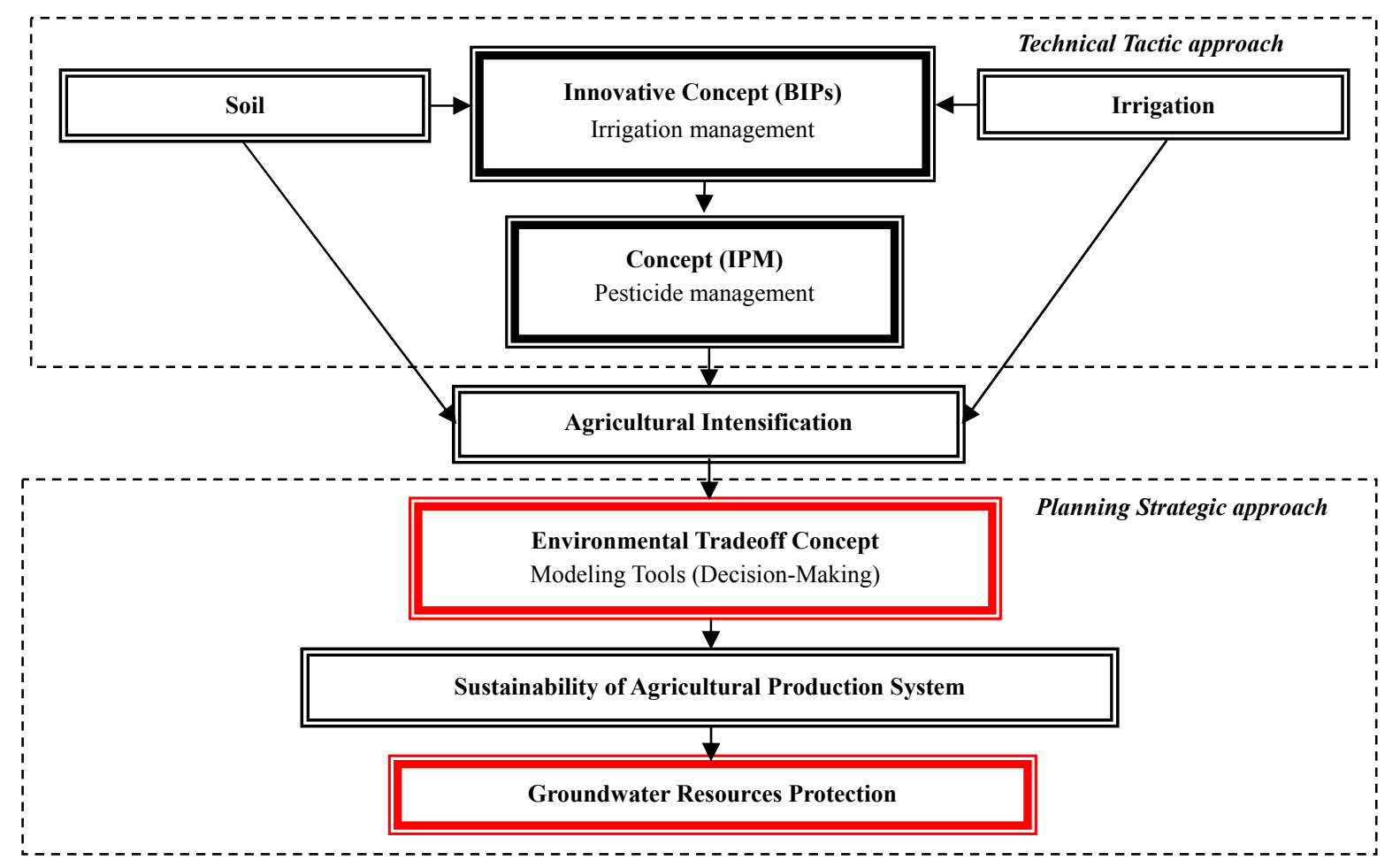

Figure 2. Environmental global approach to reduce impact from pesticides on the groundwater 


\subsubsection{Integrated Pest Management Concept (IPM)}

According to Diane (2011), the IPM is a concept, based in three keys components (Figure 3): Management, Decision-making, and Knowledge. Globally, the mains objectives of IPM concept are:

$>$ Optimize profits (over the long term);

$>$ Rational use of pesticides and minimize pesticide resistance problems, and

$>$ Reduce environmental contamination and costs-soil, groundwater, surface water, pollinators, wildlife, endangered species and sustain resource (agricultural or natural; over the long term).

To achieve these goals, the IPM concept must be supported by a key concept: BIPs which can be combined and optimized for a sustainable IPM concept. The concept of BIPs is defined as an experiment or a successful innovation, tested and validated; accepted and adopted that deserves to be circulated for greater ownership by a larger number of beneficiaries. Indeed, for the IPM concept to acquire the sustainability aspects, it should not be limited to the pesticides management, but it must consider the irrigation water resources management through the BIPs.

\section{Toolbox of Management Tactics:}

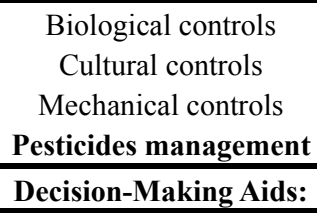

\begin{tabular}{|l|l|}
\hline Proper Pest Identification & Use of Degree-day Models \\
Pest Monitoring Methods & Economic Injury Levels \\
Evironmental Monitoring & Action Thresholds \\
\hline
\end{tabular}

Knowledge of Pest/Host/Ecosystem Biology:

\begin{tabular}{|l|l|l|l|l|}
\hline Life Cycle & Behavior & Seasonal Cycle & Population & Interactions \\
\hline
\end{tabular}

Figure 3. Schematic of IPM concept (Diane, 2011)

\subsubsection{Irrigation Management by the BIPs Innovative Concept}

Agricultural pesticides are moved through the soil by both rain and irrigation. In addition certain agricultural practices, such as tillage, the use of subsurface drains and irrigation, may appreciably contribute to pesticide leaching and subsequently to groundwater contamination (Gilliom et al., 2007). In this part of study, attention was focused on irrigation management. An adequate water supply is critical for plant growth, and various methods which can be used to supply water to plants. These different irrigation techniques influence water flow patterns in the soil (Bandaranayake et al., 1998) and solute movement in the Tunisian context, where the groundwater resources are menaced by scarcity and environmental problems. In fact, it is important to consider the best irrigation management practices BIPs that reduce pesticide leaching below the root zone, and can also enhance the water use efficiency, and hence allow gaining an economic advantage for farmers while also reducing the environmental burdens. Methods of water use efficiency and better irrigation scheduling could also integrate water and the nutrient management, thus minimizing agrochemical runoff and leaching problems. The main best irrigation practices (BIPs) approved by the major researches works are those based on the choice of irrigation system and irrigation management program. In this framework, we discuss three main BIPs that can be adopted by farmers in the tunisian context.

(1) The first BIPs is to choose an efficient irrigation system:

Many research works approved the important role of efficient irrigation system to minimize the off-site movement and the leaching problems of pesticides in the water surface and groundwater (Terry, 1993; Asare, 2000; Stephen, 2004; Gabriella, 2010). Figure 4 showed that the irrigation traditional methods are characterized by low application efficiency and a high amount of irrigation application; which gives a bad water resource valorization and an important environmental risk for the surface water and groundwater, which is mainly due to high leaching. 
a) traditional methods
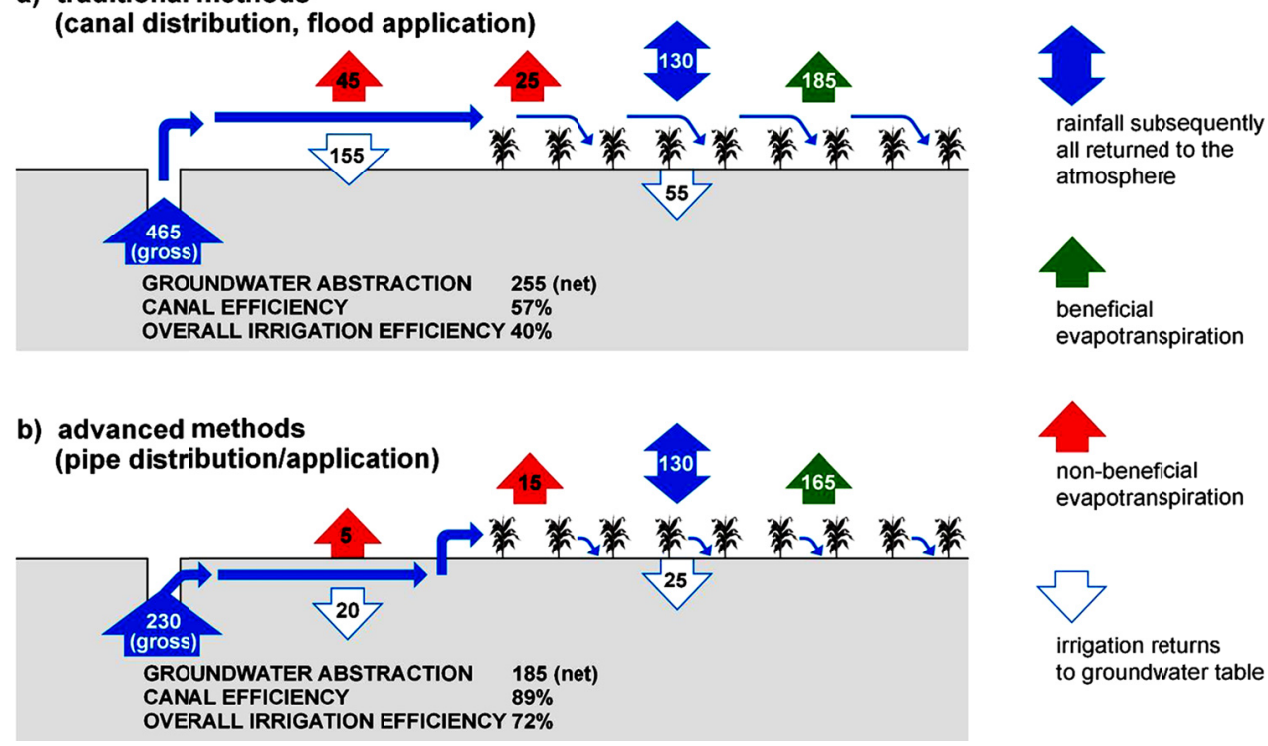

Figure 4. Interactions between Groundwater and soil-water-balance under different irrigation system and humid climatic condition (Stephen, 2004)

On the other hand, the choice of irrigation system and management of irrigation events plays a very crucial role in the off-farm pesticides movements especially through runoff phenomenon. In semi-arid tropical environment condition, Mchugh et al. (2008), have showed that the use of subsurface drip irrigation managed by deficit irrigation $(90 \%$ Etc) could help achieve economic and environmental goals by producing comparable yield to furrow irrigation coupled with increased water use efficiency, and by minimizing off-site movement of pesticides at the farm scale. In fact, Mchugh et al. (2008) showed precisely that the subsurface drip irrigation managed by deficit irrigation $(90 \%$ Etc) could reduce more the total quantities of nutrients and pesticides in the runoff and this in comparison with furrow irrigation (Figure 5).

However, with an advanced irrigation methods, we are identifying a better water irrigation saving and a lower environmental risk for the surface water and groundwater which is limited by a very low leaching. Therefore, careful choice of irrigation systems can be very effective in reducing the risk of groundwater contamination. Especially that the irrigation of 105 thousand hectares in Tunisia is ensured by the surface irrigation technique. (Hamdane \& Bachta, 2014). 

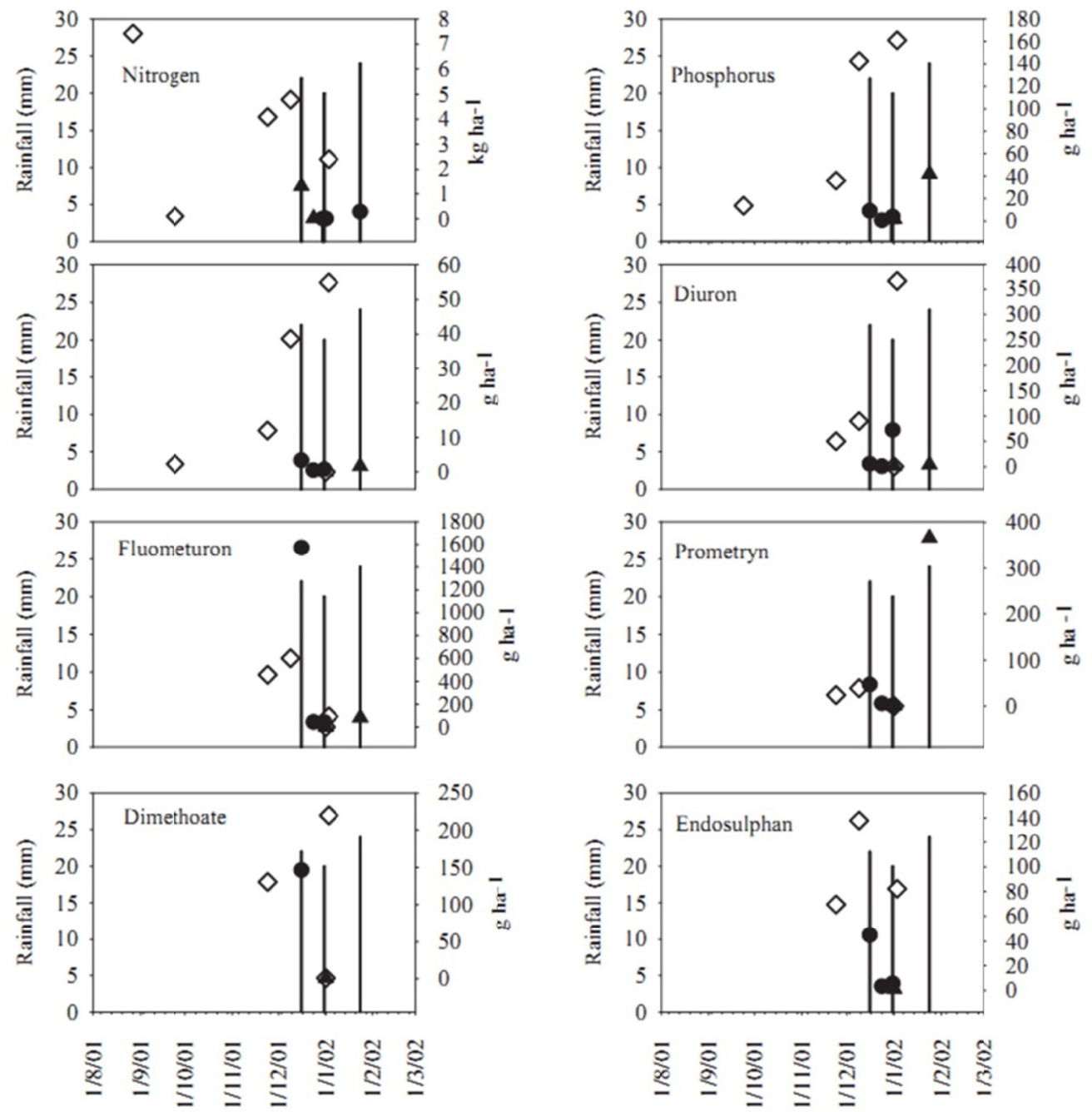

Figure 5. Total quantities of nutrients and pesticides in the runoff samples collected from each rainfall and irrigation event for furrow and subsurface irrigated sites in the first year (2001/2002)

Note. Dates are expressed in dd/mm/yy. Legend: $\diamond=$ Furrow Irrigation, $\bullet=$ Subsurface Drip Irrigation at $120 \%$ ETc, $\boldsymbol{\Lambda}$ = Subsurface Drip Irrigation at $90 \%$ ETc (Mchugh et al., 2008).

(2) The second BIPs consider the coordination between the rate and timing of irrigation and the timing of spraying to minimize pesticides loss:

This BIPs was approved by many research works. Terry (1993) has demonstrated, that the delay in water delivery allows some pesticides to degrade before water is eventually delivered onto the farmers fields. Also, Asare (2000) has approved, that the Leaching under the tensiometer-based irrigation management practices could be minimized by increasing the values of the tensiometer threshold readings at which irrigations are triggered or by delaying 3-7 days before irrigation when the recommended tensiometer threshold readings are observed. Particularly, we do note in the majority of Tunisian farmers fields, a bad synchronization between the trigger of irrigation, the spraying pesticides time and the level contamination of groundwater resource (Bahrouni et al., 2015).

(3) The third BIPs is based on the choice of irrigation scheduling practices according to soil textural:

The choice of irrigation scheduling pratices according to soil textural can be very effective to reduce the risk of groundwater contamination. Several research works have shown that the choice of scheduling practices according to soil textural can be very effective in reducing the contamination of pesticides in the groundwater contamination. The research work was carried out by Asare (2000) using the model (IRRSCHM) to evaluate the relative maximum pesticides concentrations resulting from the different irrigation scheduling practices grouped 
by soil textural classes during 30-year cropping sequence. The result of this research has demonstrated that the lowest concentrations were predicted in the case of the farmer's practices which have adopted the deficit irrigation practice (Table 2). In fact, the deficit irrigation practice has constituted a potential best irrigation practice to limit the contamination of pesticides in the groundwater.

Furthermore, the same work has proved that the predicted pesticide concentrations increased as soil sand fractions increased, regardless of the irrigation scheduling practice.

Table 2. Relative maximum pesticides (Bladex) concentrations ${ }^{\mathrm{a}}$ resulting from the different irrigation scheduling practices grouped by soil textural classes (Asare, 2000)

\begin{tabular}{lllll}
\hline \multirow{2}{*}{ Soil textural class } & \multicolumn{4}{c}{ Irrigation Scheduling Practices } \\
\cline { 2 - 5 } & Farmers practices & \multirow{2}{*}{ Irrigation at 50\% PAWD } & \multicolumn{2}{c}{ Scheduled by Tensiometer } \\
\cline { 3 - 5 } & $1.2 \mathrm{E}-18$ & $3.2 \mathrm{E}-12$ & $1.5 \mathrm{E}-06$ & 0.75 depth \\
\hline Clay & $8.4 \mathrm{E}-14$ & $2.3 \mathrm{E}-07$ & $2.2 \mathrm{E}-04$ & $6.7 \mathrm{E}-09$ \\
Clay loam & $1.0 \mathrm{E}-11$ & $2.0 \mathrm{E}-06$ & $\mathrm{~N} / \mathrm{A} \mathrm{b}$ & $\mathrm{N} / \mathrm{A} \mathrm{b}$ \\
Sandy clay loam & $6.8 \mathrm{E}-10$ & $8.9 \mathrm{E}-07$ & $4.7 \mathrm{E}-05$ & $5.5 \mathrm{E}-07$ \\
Loam & $1.6 \mathrm{E}-07$ & $9.5 \mathrm{E}-06$ & $3.0 \mathrm{E}-05$ & $9.2 \mathrm{E}-07$ \\
Sandy loam & $6.4 \mathrm{E}-07$ & $4.2 \mathrm{E}-05$ & $\mathrm{~N} / \mathrm{A} \mathrm{b}$ & $\mathrm{N} / \mathrm{A} \mathrm{b}$ \\
Loam sand & $2.4 \mathrm{E}-06$ & $4.3 \mathrm{E}-04$ & $3.2 \mathrm{E}-04$ & $1.2 \mathrm{E}-05$ \\
Sand & & &
\end{tabular}

Note. ${ }^{\text {a }}$ : predicted Bladex concentrations were divided by $1.3 \times 10^{-2} \mathrm{mg} \mathrm{L}^{-1}$, Bladex Health Adevisory level; ${ }^{\mathrm{b}}:$ No Simulation runs were made for the soil class.

In the Tunisian context, many surveys were carried out in the farms of Medjerda basin by Slatni et al. (2007), and have shown that about $50 \%$ of farmers have difficulties to master the irrigation management in terms of conversion between plant water requirement and the irrigation dose to bring along a given irrigation system.

To better control the pesticides leaching from soil to groundwater, we suggest that the best irrigation practices can be associated to soil best management practices, such as: the adding of the organic amendments to the soil (Daniel \& Rai, 2006); the use of the cover crops issued from the bed planting technique (Cassigneul et al., 2015) and the incorporate by the techniques of tillage the pesticides to soil before irrigation (B. Gabriela \& P. Graciela, 2007).

To better understand the complex processes governing leaching in the groundwater (soil properties, irrigation system management, rainfall, and groundwater depth), a research work was conducted by Gabriella et al. (2010) and aims at investigating the impact of different irrigation systems on pesticide leaching to shallow groundwater by direct monitoring at the field scale over a 3-year period. Sprinkler, border and basin irrigation systems were considered. The simulations results by MACRO 5.1 model (Table 3) have shown that the highest concentrations of pesticides were found in farms using basin irrigation, indicating that this irrigation system can influence the leaching of pesticides. Furthermore, the basin irrigation requires the greatest amount of water which is a valuable resource and should be used in a manner that maximizes crop productivity per liter. The use of this type of irrigation should be avoided in order to protect groundwater from pesticides contamination and to avoid water wastage. Border and sprinkler systems have demonstrated in a similar manner a low contamination of pesticides in the groundwater. Gabriella (2010) has deduced that the coupling of experimental results and mathematical models (IRRSCHM, MACRO) should always be considered for improving our understanding of the complex processes governing the pesticides leaching. 
Table 3. Evaluation by a MACRO 5.1 model the maximum pesticide concentration in groundwater depending on the soil properties, irrigation system management and rainfall (Gabriella et al., 2010)

\begin{tabular}{|c|c|c|c|c|c|c|}
\hline Treatments & $\begin{array}{l}\text { Topsoil Texture } \\
\text { (USAD) }\end{array}$ & $\begin{array}{l}\text { Ground-Water } \\
\text { Depth (m) }\end{array}$ & $\begin{array}{l}\text { Irrigation } \\
\text { System }\end{array}$ & $\begin{array}{l}\text { Number and } \\
\text { total amount of } \\
\text { irrigation }(\mathrm{mm}) \\
2005-2006-2007\end{array}$ & $\begin{array}{l}\text { Annual } \\
\text { Rainfall (mm) } \\
\text { 2005-2006-2007 }\end{array}$ & $\begin{array}{l}\text { Concentration of } \\
\text { Pesticides in the } \\
\text { Ground Water } \\
(\mu \mathrm{g} / \mathrm{l})\end{array}$ \\
\hline $\begin{array}{l}\text { Irrigation } \\
\text { Practice } 1\end{array}$ & Clay-loam & $0.9-2.8$ & Sprinkler & $\begin{array}{l}3-7-7 \\
120-280-280\end{array}$ & $752-625-437$ & 0.06 \\
\hline $\begin{array}{l}\text { Irrigation } \\
\text { Practice } 2\end{array}$ & Sandy-loam & $0.9-1.8$ & Sprinkler & $\begin{array}{l}6-5-7 \\
120-110-126\end{array}$ & $662-595-785$ & 0.08 \\
\hline $\begin{array}{l}\text { Irrigation } \\
\text { Practice } 3\end{array}$ & Loam & $1.1-2.8$ & Sprinkler & $\begin{array}{l}1-1-3 \\
30-50-150\end{array}$ & $1060-783-745$ & 0.38 \\
\hline $\begin{array}{l}\text { Irrigation } \\
\text { Practice } 4\end{array}$ & Sandy-loam & $0.3-2.7$ & Sprinkler & $\begin{array}{l}1-1-2 \\
30-60-60\end{array}$ & $1089-573-391$ & 0.03 \\
\hline $\begin{array}{l}\text { Irrigation } \\
\text { Practice } 5\end{array}$ & Loam & $0.5-1.8$ & Sprinkler & $\begin{array}{l}\text { 3-5-no } \\
90-125-\text {-no }\end{array}$ & $832-711-965$ & $<0.005$ \\
\hline $\begin{array}{l}\text { Irrigation } \\
\text { Practice } 6\end{array}$ & Sandy-loam & $5.3-6.7$ & Border & $\begin{array}{l}2-3-3 \\
120-180-180\end{array}$ & $561-663-349$ & 0.01 \\
\hline $\begin{array}{l}\text { Irrigation } \\
\text { Practice } 7\end{array}$ & Sandy-loam & $4.4-5.4$ & Border & $\begin{array}{l}1-2-2 \\
60-120-120\end{array}$ & $561-663-349$ & 0.01 \\
\hline $\begin{array}{l}\text { Irrigation } \\
\text { Practice } 9\end{array}$ & Sandy-clay & $3.8-5.8$ & Bassin & $\begin{array}{l}4-6-6 \\
280-420-420\end{array}$ & 716-779-689 & 1.17 \\
\hline $\begin{array}{l}\text { Irrigation } \\
\text { Practice } 10\end{array}$ & Sandy-loam & $3.6-6.9$ & Basin & $\begin{array}{l}3-5-5 \\
310-350-350\end{array}$ & $654-525-531$ & 0.34 \\
\hline No Irrigation & Loam & $0.7-3.9$ & Not-irrigation & - & $544-637-438$ & 0.08 \\
\hline
\end{tabular}

\section{Conclusions and Recommendations}

Agricultural pesticides pollution of water surface and groundwater by nutrients and pesticides has been identified as a major problem in Tunisia. Yet, in spite of major research efforts to quantify the problems and develop solutions, the significant programs and national and international funds to reduce these contaminants have not been forth coming. Actually, significant reductions in water surface and groundwater contamination by nitrate, phosphate and pesticides have been achieved that by the use of fertility and Integrated Pest Management (IPM).

However, a large extension of irrigated sector in Tunisia opts to provide at the horizon 2030 , about $50 \%$ of the total crop production. Following of these circumstances, it emerged a great challenge of the environmental tradeoff between two main pillars: Demand of irrigation and pesticides. Faced with this challenge, the judiciable solutions lies in the fact that we need to develop a global research approach that consider combination of IPM concept with the innovative concept of BIPs, and the strategic planning environmental tradeoff.

In effect, this work was focused on the role of these best practices that will feed their towers and consolidate the strategic planning concept of environmental tradeoff that takes into account to the aspect of sustainability of agricultural production system.

From this study, it was demonstrated that the environmental protection of groundwater, must consider simultaneously the pesticides management through the IPM concept and the irrigation management by the BIPs concept as two essential components to strengthen the environmental Tradeoff concept and so for the decision-making. Several relevant results of BIPs have been highlighted as part of this study. These results were from several consolidated research work by the scientific tests. The BIPs can be adopted at the farms level and have to be considered at the level of technical assistance.

In the perspective part of this work, and in order to better control the pesticides leaching from soil to groundwater, we suggest that the BIPs can be associated to BMPs, such as: the adding the organic amendments to the soil, the using the cover crops issued from the bed planting technique and the incorporating by the techniques of tillage the pesticides to soil before irrigation.

In this study we also considered the coupling between the experimental results and mathematical models (IRRSCHM, MACRO) that should always be considered for improving our understanding of the complex processes governing the leaching of pesticides in the groundwater. 
Further, advanced approaches such as biotechnology and nanotechnology could also be considered to facilitate the development of resistant genotype or pesticides with fewer adverse effects.

Finally, we closed our work by a proposition of technical support of recommendations to close and simplify the application of best irrigation practices are identified in our work, such as:

> Avoid overspray and chemical drift, especially when surface water is in close proximity to treatment area.

$>$ Avoid applications if wind speed favors drift beyond the intended application area.

$>$ Consider the time pesticide application in relation to soil moisture, anticipated weather conditions, and irrigation schedules to achieve the greatest efficiency and reduce the potential for pesticides off-site transport (drift).

Avoid pesticide application when soil moisture status or scheduled irrigation increases the possibility of runoff or deep percolation.

$>$ After pesticide application, manages irrigation to reduce the possibility of erosion, runoff and/or leaching may transport pesticide from the target site.

$>$ Ensure that backflow prevention devices are installed and operating properly on irrigation systems used for applying pesticides.

- Use GPS/GIS technology, where appropriate, to aid in pest mapping, pesticide application precision and record keeping.

\section{References}

Albarran, A., Celis, R., Hermosin, M., Lopez-Pineiro, A., \& Cornejo, J. (2004). Behavior of simazine in soil amended with the final residue of the olive-oil extraction process. Chemosphere, 54, 717-724. http://dx.doi.org/10.1016/j.chemosphere.2003.09.004

Arias-Estevez, M., Lopez-Periago, E., Martinez-Carballo, E., Simal-Gandara, J., Mejuto, J. C., \& Garcia-Rio, L. (2008). The mobility and degradation of pesticides in soils and the pollution of groundwater resources. Agriculture, Ecosystems and Environment, 123, 247-260. http://dx.doi.org/10.1016/j.agee.2007.07.011

Bahrouni, H., Ben Nouna, B., Allagui, A., Sinfort, C., Hamza, E., Chaabane, H., \& Ben Abdallah, M. A. (2015). Evaluation of Pesticides losses in Tunisian Conditions: Comparison of a drift prediction model, Drift L, with three other models. $9^{\text {th }}$ MGPR's International Symposium: Pesticides in Food and the Environment in Mediterranean Countries, October 9-10, Hammamet, Tunisia.

Bandaranayake, W. M., Butters, G. L., Hamdi, M., Prieksat, M., \& Ellsworth, T. R. (1998). Irrigation and tillage management effects on solute movement. Soil Till Res., 46, 165-173. http://dx.doi.org/10.1016/S0167-1987(98)00029-4

Carrubba, S. (2014). Vulnerability mapping of the Ghar El Melh coastal aquifer in Tunisia. Project Report. Strategic Partnership for the Mediterranean Sea Large Marine Ecosystem (Med Partnership).

Cassigneul, A., Alletto, L., Benoit, P., Bergheaud, V., Etiévant, V., Dumény, V., ... Justes, E. (2015). Nature and decomposition degree of cover crops influence pesticide sorption: Quantification and modeling. Chemosphere, 119, 1007-1014. http://dx.doi.org/10.1016/j.chemosphere.2014.08.082

Danielle, P. O., \& Rai, S. K. (2006). On-farm management practices to minimise off-site movement of pesticide from furrow irrigation. Pest Management Science, 62, 899-911. http://dx.doi.org/10.1002/ps.1255

Diane, G. (2011). The Integrated Pest Management (IPM) Concept. Published by Utah State University Extension and Utah Plant Pest Diagnostic Laboratory.

FAO. (2011). The state of the world's land and water resources for food and agriculture: Managing systems at risk. FAO Water Report, Rome.

Faurès, J.-M., Svendsen, M., \& Turral, D. (2007). Reinventing irrigation. In D. Molden (Ed.), Water for food, water for life: A comprehensive assessment of water management in agriculture (pp. 353-394). London: Earthscan; Colombo: International Water Management Institute.

Gabriela, B., \& Graciela, P. (2007). Influence of Organic Amendment on the Biodegradation and Movement of Pesticides. Environmental Science and Technology, 37, 233-271. http://dx.doi.org/10.1080/10643380 600987406

Gabriella, F., Matteo, B., Federico, F., Fabrizio, U., Ettore, C., \& Marco, T. (2010). A field study of the impact 
of different irrigation practices on herbicide leaching. European Journal of Agronomy, 32, $280-287$. http://dx.doi.org/10.1016/j.eja.2010.02.001

Gilliom, R. J., Barbash, J. E., Crawford, C. G., Hamilton, P. A., Martin, J. D., Nakagaki, N., ... Wolock, D. M. (2007). Pesticides in streams and ground water of the United States. In A. A. M. Del Re (Ed.), XIII Symposium Pesticide Chemistry-Environmental Fate and Ecological Effects of Pesticides (pp. 731-742). La Goliardica Pavese.

Hamdane, A., \& Bachta, M. S. (2014). L’intensification de l'agriculture irriguée en Tunisie (p. 85). Programme de Coopération FAO/BM.

ITE. (2014). EAU 2030-Système hydraulique de la Tunisie à l'horizon 2030.

Jensen, M. E., Rangeley, W. R., \& Dieleman, P. J. (1990). Irrigation trends in world agriculture. In B. A. Stewart, \& D. R. Nielsen (Eds.), Irrigation of Agricultural Crops (pp. 32-63). American Society of Agronomy, Crop Science Society of America, Soil Science Society of America, USA.

Jones, J. W., Tsuji, G., Hoogenboom, G., Hunt, L. A., Thornton, P. K., Wilkens, P. W., ...Singh, U. (1998). Understanding options for agricultural production. In G. Y. Tsuji, G. Hoogenboom, \& P. K. Thornton (Eds.), Decision support system for agro technology transfer: DSSAT (Vol. 3. pp. 157-177). Kluwer Academic Publishers, Dordrecht, the Netherlands.

Lal, R. (2008). Soils and sustainable agriculture: A review. Agron. Sustain. Dev., 28, 57-64. http://dx.doi.org/10.1051/agro:2007025

McBride, D. K. (1989). Managing pesticides to prevent groundwater contamination. North Dakota State University Extension Service, Publication E-979.

Mchugh, A. D., Bhattarai, S., Lotz, G., \& Midmore, D. J. (2008). Effects of subsurface drip irrigation rates and furrow irrigation for cotton grown on a vertisol on off-site movement of sediments, nutrients and pesticides. Agronomy for Sustainable Development, 28(4), 507-519. http://dx.doi.org/10.1051/agro: 2008034

Pan-Germany. (2012). Pesticide and health hazards. Facts and Figures (pp. 1-16). Retrieved October 14, 2013, from http://www.pangermany.org/download/Vergift_EN-201112-web.pdf

Saidi, S., Bouri, S., \& Ben Dhia, H. (2010). Groundwater vulnerability and risk mapping of the Hajeb-jelma aquifer (Central Tunisia) using a GIS-based DRASTIC model. Environ Earth Sci., 59, 1579-1588. http://dx.doi.org/10.1007/s12665-009-0143-0

Slatni, J., Mailhol, C., Zairi, A., Château, G., \& Ajmi, T. (2007). In A. Hammani, M. Kuper, \& A. Debbarh (Eds.), Analyse et diagnostic de la pratique de l'irrigation localisée dans les périmètres publics irrigués de la basse vallée de la Medjerda en Tunisie (p. 11). Séminaire sur la modernisation de l'agriculture irriguée, 2004, Rabat, Morocco.

Spurlok, F. (2000). Effect of irrigation scheduling on movement of pesticides to ground water in coarse soils: Monte Carlo analysis of simulation modeling. Scientific Report.

Stephen, F. (2004). The agricultural interface critical to groundwater resource status in the eu and beyond. Conference in International association of hydrogeologists the worldwide groundwater organisation.

Terry, J. L. (1993). Agricultural best management practices for water pollution control: Current issues. Agriculture, Ecosystems and Environment, 46, 223-231. http://dx.doi.org/10.1016/0167-8809(93)90026-L

Wagenet, R. J., \& Hutson, J. L. (1989). Leaching estimation and chemistry model: A process based model of water and solute movement, transformations, plant uptake, and chemical 16 reactions in the unsaturated zone. Continuum (Vol. 2, version 2). Ithaca, NY: Centre of Environmental Research, Cornell University.

Williamson, S., Ball, A., \& Pretty, J. (2008). Trends in pesticide use and drivers for safer pest management in four African countries. Crop Protection, 27, 1327-1334. http://dx.doi.org/10.1016/j.cropro.2008.04.006

\section{Copyrights}

Copyright for this article is retained by the author(s), with first publication rights granted to the journal.

This is an open-access article distributed under the terms and conditions of the Creative Commons Attribution license (http://creativecommons.org/licenses/by/3.0/). 